\title{
Küçük Renal Kitlelerde Biyopsi ve İzlem
}

\author{
Turgay Turan ${ }^{1}$, Asıf Yıldırım¹
}

${ }^{1}$ İstanbul Medeniyet Üniversitesi, Göztepe Eğitim ve Araştırma Hastanesi, Üroloji Anabilim Dalı

\section{Giriş}

G örüntüleme yöntemlerindeki teknolojik gelişmelere paralel olarak küçük renal kitlelerin tanısında artış izlenmiştir. Küçük renal kitlelerin tedavi yaklaşımları arasında aktif izlem, parsiyel/radikal nefrektomi veya ablatif tedaviler bulunmaktadır. Tedavinin temel hedefi iyi bir onkolojik ve renal fonksiyonel sonuç ile fazla tedavinin getireceği morbiditeden uzak durmak olmalıdır. Bu derlemede küçük renal kitlelerde biyopsi ve izlemin yeri detaylandırılacaktır.

\section{Biyopsi ve İzlem}

Aksiyel görüntüleme yöntemleri ile ölçülen ve $4 \mathrm{~cm}$ ve daha küçük kitlelere (cT1a) küçük renal kitleler denilmektedir. Küçük renal kitlelere tanı sonrası hemen cerrahi uygulanması hastalığın seyri hakkında yeterli bilgiye ulaşmamızı sağlamıştır. Frank ve ark.'larının 2003 yılında yayınladıkları çalışmada 4 cm'ye kadar olan kitlelerde cerrahi sonrası 221 (\%23) hastada benign lezyon tespit etmişlerdir (1). Thompson ve ark'ları 2009 yılında yayımladıkları çalışmalarında $4 \mathrm{~cm}$ ve daha küçük boyutlu kitlelerde metastaz riskini $\% 2$ olarak bildirmişlerdir (2). Küçük renal kitlelerde aktif izlemin kansere özgü sağkalımı ve genel sağkalımı olumsuz yönde etkilemediğini bildiren çalışmalar literatürde yer almaktadır $(3,4)$.

Avrupa Üroloji Derneği 2016 yılı Böbrek Kanseri Kılavuzu renal kitle biyopsisini ablatif tedavi ve sistemik tedavi öncesi veya aktif izlem yapılması planlanan hastalarda önermektedir (öneri derecesi: C) (5). Bu konudaki çalışmaların birisinde Richard ve ark.'ları 509 hastanın dahil edildiği çalışmalarında, böbrek biyopsisi ile \%4.7 oranında perirenal hematom, $\% 2.4$ oranında ko-aksiyel hattında venöz kanama ve \%1 oranında kendi-kendine sınırlanan gros hematüri bildirmişlerdir. Perirenal hematomu olan 1 hastaya selektif anjioembolizasyon yapılmıştır. Yine aynı çalışmada 131 hastada (\%26) benign patoloji tespit edilmiştir (6). Hu ve ark.'larının 301 perkütan renal biyopsi sonuçlarını yayınladıkları çalışmalarında ise; benzer şekilde \%23 hastada benign patoloji tespit edilmiştir (7). Bu çalışmada tanı koyduruculuk oranı \%89 ve renal hücreli karsinom (RCC) alt tipini doğru belirleme oranı ise \%93 olarak bildirilmiştir. Radikal nefrektomi sonrası 55 hastanın tamamında RCC tanısı \%100 doğrulukla teyit edilirken, yalnızca 4 hastada RCC alt tipi doğru tespit edilememiştir. Sonuç olarak renal biyopsinin kesin tanı koyduruculuğunun yanında tedavi kararında da önemli rol oynayabileceği belirtilmiştir.

Bunların yanında, Marconi ve ark'larının yayımladıkları ve perkütan kor biyopsi ve ince iğne aspirasyon biyopsisini karşılaştırdıkları meta-analizde 57 çalışmada toplam 5.228 hasta incelenmiştir (8). Buna göre, böbrek biyopsisi ile \%92 hastada tanı konulabilmektedir. Her iki yöntemin özgüllük ve duyarlılık oranları sırasılya perkütan kor biyopsi için \%99.7 ve \%99.1 iken ince iğne aspirasyon biyopsi için $\% 89.8$ ve \%93.2 olarak bildirilmiștir. Meta-analize alınan tüm çalışmalar gözden geçirildiğinde yalnıza 3 hastada Clavien $\geq 2$ komplikasyon bildirilmiştir. Sonuç olarak bu çalışmada renal kitle biyopsinin deneyimli merkezlerde yüksek tanısal değere sahip olduğu ve her iki tekniğin de geçerli yöntemler olduğu belirtilmiştir. Bunun yanında, Ambani ve ark'larının yaptıkları 118 hastanın 29.5 ay süre ile aktif olarak izlendiği retrospektif çalışmada ise; tümöre geç müdahale kararında biyopsi yapılmasından çok, tümörün yıllık büyüme hızı ve ilk tanı anında tümörün boyutunun önemli olduğu bildirilmiştir (9). Diğer bir retrospektif çalışmada ise; renal nefrometri skoru, renal nefrometri skoru temelli nomogramlar veya bunların kombinasyonları "radyolojik renal kitle boyutu ve biyopsi"ye göre yapilan tedavi kararı risk sinıflamasinda ek katkı sağlamadığı raporlanmıştır (12). Pierorazio ve ark.'larının yaptıkları 5 yıllık prospektif çalışmada ise; aktif izlem grubuna alınan 223 hastanın $21(\% 9)^{\prime}$ 'ine geç tedavi yapılmıştır. 3 Aktif izlem grubunda genel olarak yaşlı, kötü ECOG (Eastern Cooperative Oncology Group) skoru olan, kardiyovasküler komorbiditesi bulunan, multipl ve bilateral tümörlü olgular yer almıştır. Hastaların uzun dönem takibi sonunda her iki grup arasında genel sağkalım ve kansere özgü sağkalım açısından fark bulunmamıştır.

Perkütan renal biyopsi, aktif izlem veya ablatif tedavi planlanan hastaların yanında metastatik hastalığın medikal tedavisi öncesinde renal kitlenin histolojik tanısı için de kullanılmaktadır. Ancak, renal kitlelerde kesitsel görüntülemelerin yüksek tanısal doğruluğu nedeniyle cerrahi planlanan hastalara biyopsi önerilmez. Biyopsi benzer tanısal doğruluk ile ultrasonografi veya tomografi eşliğinde perkütan kor biyopsi veya ince iğne aspirasyon biyopsisi şeklinde yapılabilir. Solid kitleler için perkütan kor biyopsi tercih edilmeli, en az iki kor biyopsi alınmalıdır. Santral nekroz riski nedeniyle periferal örnekleme yapılmalıdır. Biyopsi için düşük morbidite oranıyla, tanı için yeterli doku örneği sağlayan $18 \mathrm{G}$ iğne idealdir. Tümör ekiminden kaçınmak ve birden fazla biyopsi almaya yardımcı olması bakımından ko-aksiyel kanül kullanılması önerilmektedir (10). Biyopsi sonrası tanı 
konulamadı ise; tekrar biyopsi veya cerrahi müdahale gerekebilir. Tekrar biyopsilerde yüksek oranda tanısal yeterlilik mevcuttur (\%83-100) (11). Ancak şunu da belirtmek gerekir ki; biyopsinin histolojik doğruluk oranı yüksek iken (\%90), nükleer derecelendirmede doğruluk oranı yetersizdir (\%62) (8).

Sınırlı yaşam beklentisi olan veya sistemik hastalıkları nedeni ile tedavi için yüksek riski bulunan hastalara aktif izlem önerilmektedir (13). Bunun yanında ASCO 2017 küçük renal kitleler için kılavuz önerisinde tedavi kararını etkileyecekse biyopsi yapılması önerilmektedir (14).

\section{Sonuç}

Küçük renal kitlelerin prognozu hakkında bilgi sahibi olmak ve uygun hastalara aktif izlem önerisinde bulunabilmek için biyopsi yapmak güvenli ve etkilidir. Deneyimli merkezlerin tanisal doğrululuğu ve biyopsi doku örneği yeterliliği yüksektir. Bu yüzden aktif izlem planlanan hastalara biyopsi yapılması için tecrübeli merkezlere yönlendirilmesi önerilir.

\section{Kaynaklar}

1. Frank I, Blute ML, Cheville JC, Lohse CM, Weaver AL, Zincke H. Solid renal tumors: an analysis of pathological features related to tumor size. J Urol 2003; 170:2217-20.

2. Thompson RH1, Hill JR, Babayev Y, Cronin A, Kaag M, Kundu S, Bernstein M, Coleman J, Dalbagni G, Touijer K, Russo P. Metastatic renal cell carcinoma risk according to tumor size. J Urol 2009; 182: 41-5.

3. Pierorazio PM, Johnson MH, Ball MW, et al. Five-year Analysis of a Multiinstitutional Prospective Clinical Trial of Delayed Intervention and Surveillance for Small Renal Masses: The DISSRM Registry. Eur Urol 2015: 2-9.

4. Smaldone MC, Kutikov A, Egleston BL, et al. Small renal masses progressing to metastases under active surveillance: a systematic review and pooled analysis. Cancer 2012; 118: 997-1006.

5. Ljungberg B., Bensalah K., Bex A, et al. EAU guidelines on Renal Cell Carcinoma. Limited Update March 2016.

6. Richard PO, Jewett MA, Bhatt JR, Kachura JR, Evans AJ, Zlotta AR, et al. Renal tumor biopsy for small renal masses: A Single-center 13-year Experience. Eur Urol 2015; 68: 1007-13.
7. Hu R, Montemayor-Garcia C, Das K. Role of percutaneous needle core biopsy in diagnosis and clinical management of renal masses. Hum Pathol 2015; 46: 570-6.

8. Marconi L, Dabestani S, Lam TB, Hofmann F, Stewart F, Norrie J et al. Systematic review and meta-analysis of diagnostic accuracy of percutaneous renal tumour biopsy. Eur Urol 2016; 69: 660-73.

9. Ambani SN, Morgan TM, Montgomery JS, Gadzinski AJ, Jacobs BL, Hawken S. Predictors of delayed intervention for patients on active surveillance for small renal masses: Does renal mass biopsy influence our decision? Urology 2016; 98: 88-96.

10. Tsivian M, Rampersaud EN Jr, del Pilar Laguna Pes M, Joniau S, Leveillee RJ, Shingleton WB et al. Small renal mass biopsy--how, what and when: report from an international consensus panel. BJU Int 2014; 113:854-63.

11. Leveridge MJ, Finelli A, Kachura JR, Evans A, Chung H, Shiff DA et al. Outcomes of small renal mass needle core biopsy, nondiagnostic percutaneous biopsy, and the role of repeat biopsy. Eur Urol 2011; 60: 578-84.

12. Osawa T, Hafez KS, Miller DC, Montgomery JS, Morgan TM, Palapattu GS et al. Age, Gender and R.E.N.A.L. Nephrometry Score do not improve the accuracy of a risk stratification algorithm based on biopsy and mass size for assigning surveillance versus treatment of renal tumors. J Urol 2016; 195: 574-80.

13. Ahmad AE, Finelli A, Jewett MA. Surveillance of Small Renal Masses. Urology 2016; 98: 8-13.

14. Finelli A, Ismaila N, Bro B, Durack J, Eggener S, Evans A et. al. Management of Small Renal Masses: American Society of Clinical Oncology Clinical Practice Guideline. J Clin Oncol 2017 17:JCO2016699645. doi: 10.1200/ JCO.2016.69.9645. [Epub ahead of print]

Yazışma Adresi:

Asif Yildirım,

İstanbul Medeniyet Üniversitesi, Göztepe Ĕ̆itim ve Araştırma Hastanesi, Üroloji Anabilim Dal, Fahrettin Kerim Gökay Caddesi, Kadıköy, Istanbul

Tel: +905323430723

e-mail: asifyildirim@yahoo.com 